\title{
PEMBUATAN SISTEM LAZM (LEMBAGA AMIL ZAKAT MASJID) JAKARTA BERBASIS WEB
}

\author{
${ }^{1}$ Sri Chusri Haryanti, ${ }^{2}$ Ahmad Thohirien, dan ${ }^{3}$ Nurul Huda \\ 1,2 Teknik Informatika, Teknologi Informasi, Universitas YARSI, Jakarta \\ ${ }^{3}$ Program Magister Manajemen, Universitas YARSI, Jakarta \\ E-mail: ${ }^{1}$ sri.chusri@yarsi.ac.id, ${ }^{2}$ ahmad.thohirin@students.yarsi.ac.id, ${ }^{3}$ nurul.huda@yarsi.ac.id
}

\begin{abstract}
Utilizing Information Technology (IT) in managing the Zakat not only could support muzzakis (people who give Zakat donation) and zakat institution but also provide accountability and transparency. Both liability and transparency could increase the people's trustiness to the zakat institution. In the end, it could raise Islamic social welfare. This research has produced a web-based system for LAZM (Lembaga Amil Zakat Mesjid) institutions to facilitate the muzakkis in donating the Zakat anytime and anywhere. Guiding the institution in calculating the number of donations obtained, keeping the muzakkis' data, distributing the donations, and creating the donations' report to the BAZNAS are the system features. This system also builds the network between LAZM institutions for the easiness of sharing funds and data. Assisting Muzzakis in finding the nearest mosque to distribute the Zakat, the system presents the map of the mosques.
\end{abstract}

Keywords: amil, mosque, zakat, muzzaki

\begin{abstract}
Abstrak
Penggunaan teknologi informasi (TI) dalam pengelolaan dana zakat, selain memudahkan muzaki (orang yang berzakat) dan pengelola, juga dapat memberikan akuntabilitas dan transparansi pengelolaan zakat. Akuntabilitas dan transparansi pengelolaan zakat dapat meningkatkan kepercayaan masyarakat kepada pengelola zakat dan pada akhirnya akan dapat meningkat kesejahteraan masyarakat muslim pada umumnya. Penelitian ini menghasilkan sistem untuk lembaga amil zakat masjid berbasis web yang mempermudah muzaki mendonasikan zakatnya, karena dapat diakses kapanpun dan dimanapun. Sistem ini juga membantu pengelola zakat dalam melakukan perhitungan jumlah donasi yang terkumpul, menyimpan data muzaki, menyalurkan donasi dan membuat laporan kepada BAZNAS. Dalam sistem ini, lembaga amil zakat pada satu masjid terhubung dengan lembaga amil zakat masjid lainnya sehingga memudahkan berbagi dana dan data. Sistem ini juga menampilkan peta masjid yang terhubung dalam sistem, sehingga memudahkan user (muzakki) mencari masjid terdekat untuk tempat menyalurkan zakatnya.
\end{abstract}

Kata Kunci: amil, masjid, zakat, muzzaki

\section{Pendahuluan}

Zakat merupakan satu-satunya ibadah yang dalam syariat Islam yang secara eksplisit dinyatakan memiliki petugas. Ada dua model pengelolaan zakat. Pertama, zakat dikelola oleh negara dalam sebuah lembaga atau departemen khusus yang dibentuk oleh pemerintah. Kedua, zakat yang dikelola oleh lembaga non-pemerintah (masyarakat) atau semi pemerintah dengan mengacu pada aturan yang telah ditentukan oleh negara salah satunya adalah masjid (Jafar, 2013).

Indonesia memiliki badan yang menerima, mengelola dan menyalurkan zakat yang bernama Badan Amil Zakat Nasional (BAZNAS). Selain itu juga terdapat lembaga pengumpul dan pengelola zakat independen. Menurut Undang-undang No 23 Tahun 2011, lembaga-lembaga independen tersebut harus melaporkan perolehan dan penyaluran zakatnya kepada BAZNAS secara 
berkala.

Seiring dengan perkembangan teknologi, pengurus LAZM dituntut untuk terus-menerus mengikuti perkembangan teknologi guna untuk meningkatkan kualitas dan memperbaharui informasi muzakki yang akan dibutuhkan sewaktuwaktu. Komputerisasi dalam pengelolaan informasi zakat di sebuah lembaga amil zakat memegang peranan yang cukup penting, terutama menyangkut data pelaporan.

Selama ini sebagian besar lembaga amil zakat mempunyai pengarsipan data Muzakki dalam bentuk formulir bukti setor zakat maal. Sering sekali ditemui kendala pada saat pencarian data tentang Muzakki, dan pembuatan laporan data muzakki. Terkadang data muzakki yang dicari tidak ada atau formulir bukti setor zakat yang dicari telah hilang, sehingga untuk mengetahui data Muzakki tersebut membutuhkan waktu yang lama karena harus mencari data satu persatu terlebih dahulu di dalam tempat bukti setor Zakat Maal. Guna mengatasi kendala yang dihadapi selama ini maka bagian pengurus Lembaga Amil Zakat Masjid (LAZM) Jakarta dituntut untuk terus menerus mengikuti perkembangan teknologi guna untuk mengembangkan serta memperbaharui proses bisnis yang sudah berjalan.

Pada penelitian ini, dibuat sistem LAZM yang membantu amil dan mempermudah muzakki mendonasikan zakatnya dengan cara transfer ke nomor rekening yang sudah disediakan di dalam sistem LAZM. Kelebihan lain dari sistem ini adalah dapat menyediakan kalkulator zakat dan muzakki dapat memilih masjid terdekat sebagai tempat donasi. Dengan demikian proses pengarsipan data dapat dilakukan dengan cepat, serta pada saat data muzakki tersebut dibutuhkan kembali dapat dengan mudah diperoleh datanya.

Hasil penelitian ini diharapkan menjadi media bantu bagi pengelola zakat seluruh masjid di Jakarta dalam melakukan perhitungan jumlah donasi yang didapat seluruh masjid di Jakarta, penyimpanan data muzakki, dan keputusan penyalur donasi yang akan diberikan.

\section{Tinjauan Pustaka}

Sejauh ini telah banyak sistem informasi atau aplikasi yang dibuat untuk memudahkan pengelolaan zakat, baik yang berbasis web (Hidayat, 2017) maupun mobile (Mirtasari, 2018). Sistem-sistem tersebut lebih difokuskan untuk memudahkan muzakki dalam menyalurkan zakatnya. Sistem tersebut belum mempertimbangkan masjid sebagai lembaga pengumpul zakat maupun penyaluran dana zakat kepada para mustahik.

Pengelolaan dana zakat di negara tetangga, Malaysia, telah lebih tertata dan tertib. Sama seperti di Indonesia, masjid juga merupakan lembaga pengumpul zakat. Dahlan dkk. mengusulkan Program e-ZAKAT4U sebagai solusi dalam penyaluran zakat melalui masjid yang saling terhubung (network-of-mosque) (Dahlan dkk., 2015). Program e-ZAKAT4U lebih fokus kepada peningkatan dan pemerataan penyaluran daripada pengumpulan dana zakat.

\section{Deskripsi Umum Sistem}

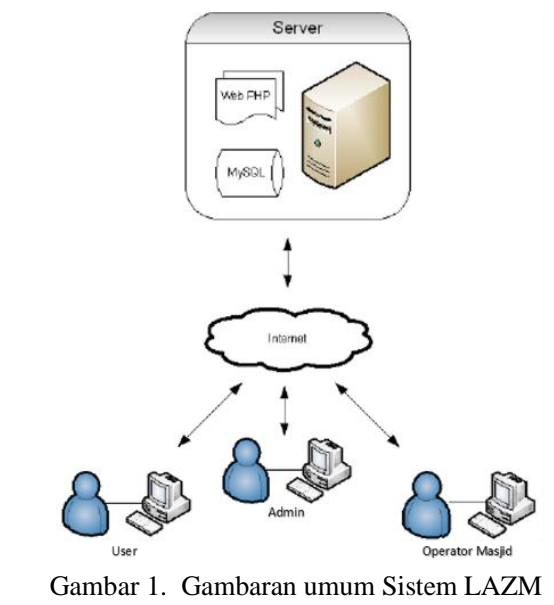

Model sistem informasi yang dibangun pada penelitian ini merupakan sistem informasi yang sesuai dengan kebutuhan masyarakat dan lembaga zakat yang ada di Indonesia. Di satu sisi, muzzaki perlu difasilitasi untuk mudah dalam menghitung dan menyalurkan zakatnya. Dari sisi lembaga, sistem informasi ini memudahkan pencatatan, pengelolaan, penyaluran dan pelaporan zakat ke BASNAZ. Dari sisi mustahik, sistem informasi ini memudahkan penentuan dan penyaluran dana zakat kepada mustahik yang berhak mendapat zakat.

Dalam sistem ini, lembaga amil zakat pada satu masjid terhubung dengan lembaga amil zakat masjid lainnya sehingga memudahkan berbagi dana dan data. Sistem ini juga menampilkan peta masjid yang terhubung dalam sistem, sehingga memudahkan user (muzakki) mencari masjid terdekat untuk tempat menyalurkan zakatnya. Peta masjid ditampilkan pada sistem informasi dengan bantuan sistem informasi geografis (Chrisman, 1997).

Gambar 1 memperlihatkan gambaran umum sistem yang dibuat. Sistem informasi zakat merupakan sistem berbasis website yang menggunakan script HTML serta PHP sebagai pembangun antar muka dan fungsi-fungsinya, 
sedangkan untuk menyimpan data-data yang diperlukan menggunakan basis data MySQL.

Sistem ini dibangun guna mempermudah pihak LAZM dalam menginformasikan programprogram serta agenda kegiatan lembaganya kepada muzakki yang dalam sistem disebut sebagai user, memperkenalkan profil LAZM kepada user, mempermudah LAZM dalam mengatur setiap data user, melaporkan aliran dana zakat yang telah masuk dan disalurkan oleh LAZM, juga kalkulator zakat untuk mempermudah user menghitung besarnya zakat yang harus dikeluarkan.

\section{Perancangan Model}

\subsection{Use case diagram}

Use case diagram pada sistem LAZM menggambarkan beberapa atau seluruh aktor dengan tujuan mendeskripsikan interaksi dalam sistem Sistem LAZM. Berikut merupakan gambaran use case model pada sistem LAZM.

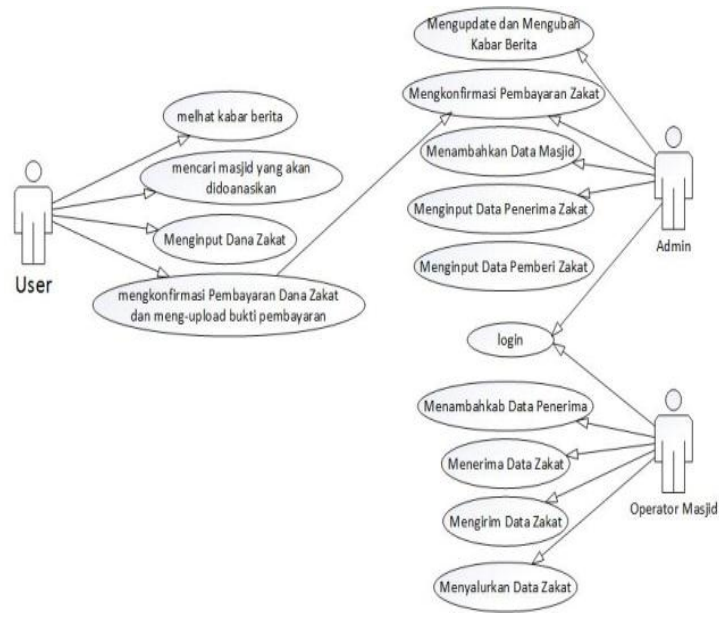

Gambar 2. Use Case Diagram Sistem LAZM

Sistem LAZM memiliki 3 aktor yaitu user (muzakki), admin, dan operator masjid. User dapat memilih masjid yang sudah disediakan oleh admin. User dapat memasukkan data diri dan melakukan perhitungan zakat yang akan dikeluarkan dengan kalkulator yang sudah disediakan. User dapat meng-upload bukti pembayaran yang sudah ditransfer dan melihat data para muzakki dan mustahiq di setiap masjid, serta dapat melihat kabar berita terbaru melalui sistem LAZM. Admin dapat melihat data masjid, data pemberi dan penerima. Admin dapat mengubah atau mengupdate data masjid, data pemberi dan penerima. Serta admin dapat melakukan konfirmasi pemberi donasi dengan melihat dana tanda bukti pemberi donasi melalu sistem LAZM. Sedangkan Operator Masjid dapat melakukan tambah data penerima, menerima dana zakat dan melakukan penyaluran dana zakat kepada yang berhak menerima donasi melalui sistem LAZM.

\subsection{Sequence Diagram}

Sequence diagram sistem LAZM dapat dilihat dari tiga sisi aktor. Gambar 3 memperlihatkan sequence diagram dari sisi user. Aktivitas mulai dari user memilih masjid. Controller menampilkan hasil data masjid dalam bentuk maps. Apabila user sudah memilih masjid terdekat yang akan didonasikan, user memasukkan data identitas diri atau semua data yang diperlukan. Apabila data sudah diisi, semua controller akan mencek data apakah sudah sesuai atau belum. Apabila data sesuaimaka data akan disimpan ke dalam database. Setelah berhasil disimpan maka akan ada notifikasi sukses. Bila user mendonasikan zakatnya, user perlu meng-upload gambar (bukti transfer). Apabila sukses maka gambar akan disimpan di database dan menampilkan notifikasi sukses.



Gambar 3. Sequence diagram user

Gambar 4 menunjukkan sequence diagram untuk admin. Aktivitas mulai dari admin memasukan username dan password untuk login. Controller memeriksa, apabila username dan password sesuai maka admin dapat masuk ke halaman dashboard dan dapat melakukan input pada master data dengan memilih konfirmasi pembayaran zakat yang akan dicek lebih dahulu. Setelah melakukan proses penyimpanan data konfirmasi pembayaran maka data akan disimpan ke dalam database dan menampilkan laporan. 




Gambar 4. Sequence diagram admin

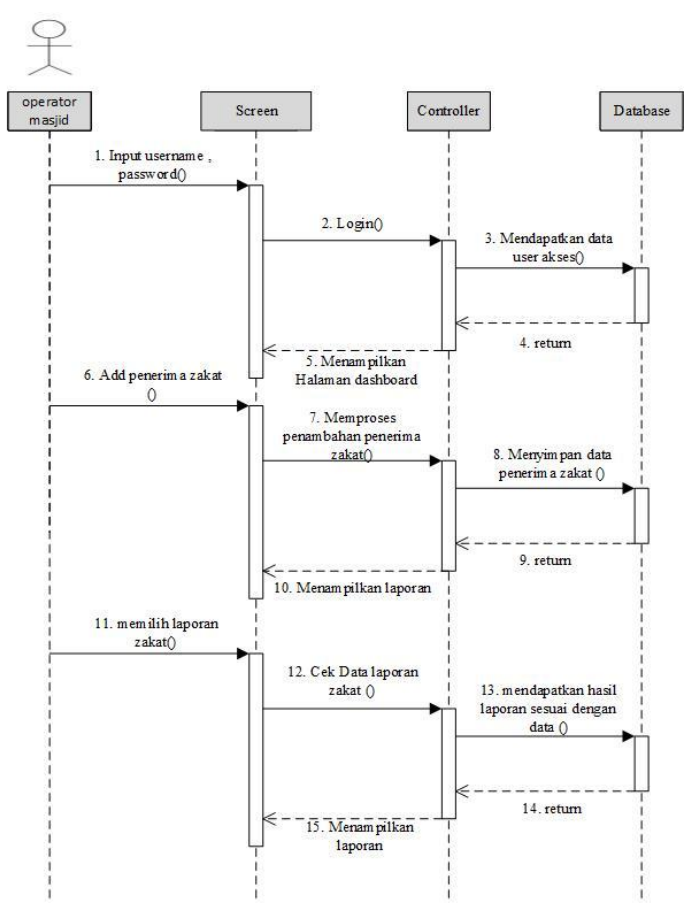

Gambar 5. Sequence diagram operator masjid

Sequence diagram operator masjid ditunjukkan oleh Gambar 5. Operator masjid dapat menambahkan penerima zakat. Aktivitas mulai dari operator masjid memasukan username dan password untuk login. Controller memeriksa, apabila username dan password sesuai maka operator masjid dapat masuk ke halaman dashboard. Selanjutnya operator masjid dapat melakukan penambahan penerima zakat dan menyimpan data penerima zakat. Setelah operator masjid melakukan proses penyimpanan maka data akan disimpan ke dalam database dan dapat ditampilkan sebagai laporan.

\subsection{Activity Diagram}

Activity diagram pada sistem LAZM memperlihatkan aliran dari suatu aktivitas ke aktivitas lainnya. Gambaran aktivitas sistem LAZM dapat dilihat pada Gambar 6 .

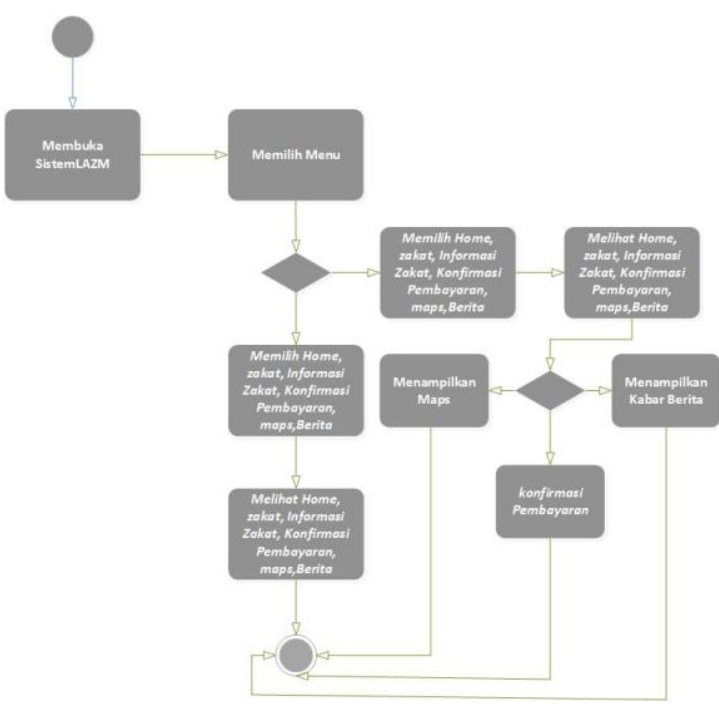

Gambar 6. Activity Diagram Sistem LAZM

Aktivitas dimulai dengan user memilih menu, yaitu memilih Home, Zakat, Informasi Zakat, konfirmasi pembayaran, melihat maps masjid yang akan didonasikan dan kabar berita tentang zakat yang masing-masing akan menampilkan informasi yang berbeda. Daftar menu yang disediakan memiliki aktivitas lainnya yaitu, memilih menu maps dimana terdapat peta lokasi masjid yang sudah ditergabung dalam Sistem LAZM untuk mendonasikan dana. Menu selanjutnya yang dipilih adalah konfirmasi pembayarandengan cara melakukan upload tanda bukti transfer yang sudah dilakukan yang nantinya akan tampil dimenu informasi zakat.

\section{Implementasi}

Halaman Home sistem LAZM merupakan website yang dikhususkan untuk user melihat informasi tentang zakat dan membantu user untuk penyaluran zakat. Home sistem LAZM dapat dilihat pada Gambar 7. 


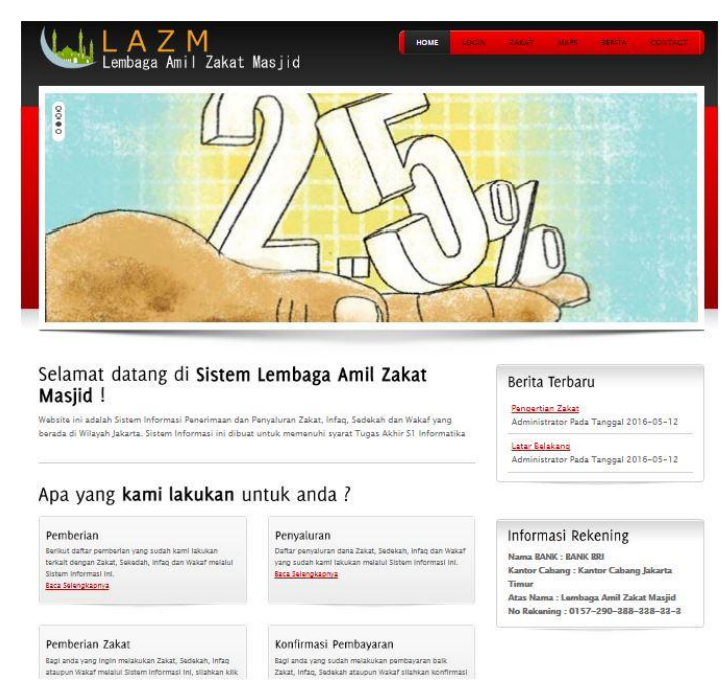

Gambar 7. Home Sistem LAZM

Pada halaman menu peta sistem LAZM, user dapat memilih masjid tempat user mendonasikan dana (Gambar 8). User bisa melihat lokasi masjid yang berada di seluruh wilayah Jakarta, berikut dengan nama masjid dan total dana yang sudah dimiliki oleh masjid tersebut. User juga bisa mendonasikan dana yang ingin didonasikan dengan memilih salah satu masjid yang terdekat.

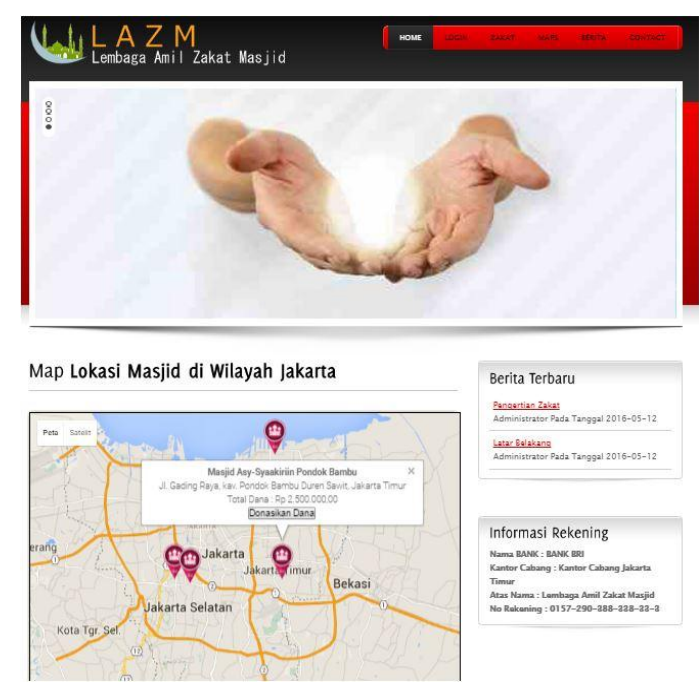

Gambar 8. Sistem LAZM dengan map

Halaman donasi dana pada sistem LAZM adalah halaman yang dikhususkan untuk user mendonasikan dana setelah memilih masjid terdekat yang sudah disediakan (Gambar 9).

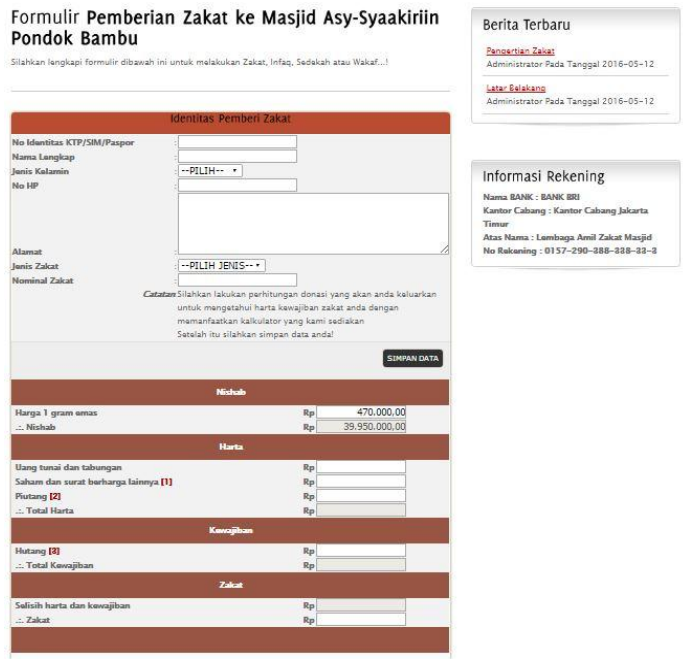

Gambar 9. Halaman Donasikan Dana Sistem LAZM

Gambar 9 merupakan tampilan dari donasikan dana yang dipilih user dari peta masjid yang sudah disediakan. Selanjutnya user dapat mengisi formulir pemberian zakat ke masjid yang sudah dipilih user. Di dalamnya juga terdapat kalkulator mengenai perhitungan zakat, infaq, sedekah dan waqaf yang sudah dirumuskan. Setelah user mengisi data diri, dan jenis zakat apa yang dipilih, user dapat memanfaatkan kalkulator yang sudah disediakan. Kalkulator zakat,memudahkan muzakki mengetahui nominal zakat yang harus dikeluarkan dan selanjutnya user melakukan simpan data.

Untuk konfirmasi pembayaran pada sistem LAZM, user mengisi form konfirmasi dan melakukan upload bukti pembayaran yang sudah dilakukan (Gambar 10).

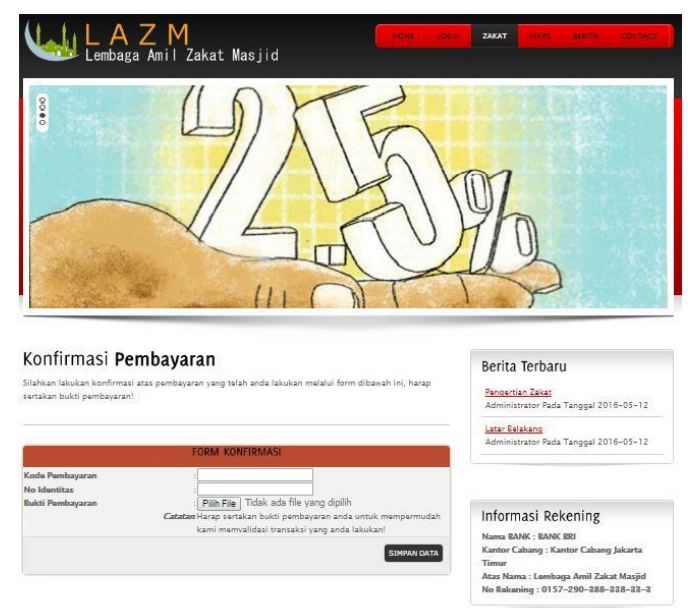

Gambar 10. Halaman Konfirmasi Pembayaran Sistem LAZM 




Gambar 11. Menu admin sistem LAZM

Gambar 11 memperlihatkan tampilan halaman admin, di mana admin bisa melakukan tambah data masjid, melihat data pemberi zakat, menambahkan data penyalur zakat dan menvalidasi data yang belum dikonfirmasi.

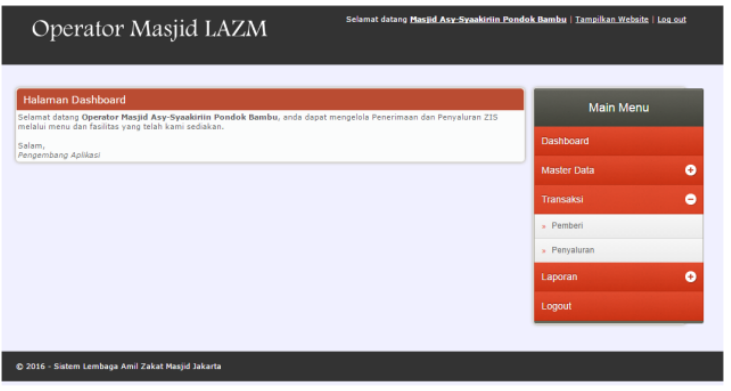

Gambar 12. Menu operator masjid Sistem LAZM

Gambar 12 memperlihatkan halaman operator masjid, di mana operator masjid dapat melakukan melihat laporan data pemberi dan operator masjid juga dapat menambahkan data penyaluran, seperti: nama, alamat, dan mengisi berapa total dana yang ingin diberikan untuk penerima zakat, infaq sedekah, dan waqaf.

\section{Pengujian}

Sistem informasi LAZM yang dihasilkan pada penelitian ini diujikan kepada pengurus dari 10 masjid. Pengujian dilakukan dengan meminta responden menggunakan sistem LAZM dan mengukur tingkat kepuasan responden terhadap sistem tersebut. Hasil pengujian tersebut dapat dilihat pada Tabel 1 .
Tabel 1. Hasil pengujian kepuasan user terhadap sistem informasi LAZM

\begin{tabular}{|c|l|c|}
\hline No & \multicolumn{1}{|c|}{ Elemen Kepuasan } & $\begin{array}{c}\text { Hasil } \\
\text { Pengujian } \\
\mathbf{( \% )}\end{array}$ \\
\hline 1 & Sistem LAZM menarik & 86 \\
\hline 2 & Sistem LAZM mudah digunakan & 90 \\
\hline 3 & $\begin{array}{l}\text { Pengguna ingin mengakses sistem } \\
\text { LAZM di HP sendiri }\end{array}$ & 92 \\
\hline 4 & $\begin{array}{l}\text { Pengguna akan menyarankan orang } \\
\text { lain menggunakan sistem LAZM }\end{array}$ & 90 \\
\hline 5 & Ukuran huruf pada layar sesuai & 92 \\
\hline 6 & Komposisi warna sesuai & 92 \\
\hline 7 & Gambar yang di tampilkan menarik & 86 \\
\hline 8 & $\begin{array}{l}\text { Tombol-tombol mudah dimengerti } \\
\text { dan digunakan }\end{array}$ & 96 \\
\hline \multicolumn{2}{|l|}{ Hasil Pengujian Kepuasan } & 90,5 \\
\hline
\end{tabular}

\section{Kesimpulan}

Berdasarkan implementasi yang sudah dilakukan serta uraian-uraian yang telah dikemukakan pada sebelumnya, dapat disimpulkan sebagai berikut :

a. Pada penelitian ini telah dihasilkan sebuah sistem lembaga amil zakat masjid Jakarta LAZM, yaitu informasi masjid, pemberian donasi, dan penyaluran dana donasi kepada yang berhak menerima.

b. Pada penelitian ini telah dihasilkan sebuah sistem WEB yang memudahkan para lembaga amil zakat masjid dalam memproses penerimaan pembayaran zakat.

\section{Daftar Pustaka}

Chrisman, N., 1997, Exploring Geographic Information System, John Wiley and Sons, Inc. New York.

Dahlan, A.R.A., Awang, S.N., Mahmood, A., 2015, 'e-ZAKAT4U Program: Enhancing Zakat Distribution System by Merging with Networkof-Mosque (NoM)', International Journal of Management and Commerce Innovations, 3.1, pp. 264-268.

Hidayat, A., \& Fahri, S., 2017, 'Perancangan Sistem Informasi Pengolahan Data Zakat Fitrah Berdasarkan Perhitungan Badan Amil Zakat', Jurnal Manajemen Informatika (JUMIKA), 4(2).

Jafar F., 2013, Peran dan Fungsi Masjid dalam Kehidupan, unpublish.

Mirtasari, D., \& Februariyanti, H., 2018, 'Perhitungan Zakat Harta dan Zakat Profesi Berbasis Android', Prosiding SINTAK 2018. https://www.unisbank.ac.id/ojs/index.php/sinta $\mathrm{k} /$ article/view/649 